\title{
POLITIK HUKUM PENANGGULANGAN TINDAK PIDANA TERHADAP PEDAGANG KAKI LIMA
}

\author{
Fitri Setiyani Dwiarti \\ KADIN Provinsi Lampung \\ Email : data232007@yahoo.com
}

\begin{abstract}
This research aimed to describe the choice of law carried out by Local Government of Bandar Lampung in tackling illegal activities of street vendors in the Bambu Kuning Market. By using normative approach and utilizing secondary data, it could be concluded that use of a means of penal or (law) criminal in a policy is a way to streamline the implementation of the regulation. In addition, it can be concluded that the existence of criminal in a regulation will only be effective if: 1) the criminal is seriously preventing, 2) criminal it does not cause an even more dangerous or harmful than would occur if the criminal is not charged, and 3) no other criminal that can effectively prevent the harm or loss smaller. The provision of criminal sanctions in a regulation serves to prevent the occurrence of crime, and in addition, if a crime has occurred, then the function of criminal provisions is to give deterrent effect to the perpetrators.
\end{abstract}

Keywords: Legal Politics, Criminal Law and Street Vendors.

\section{abstrak}

Penelitian ini bertujuan untuk menjabarkan pilihan hukum yang dilakukan pemerintah daerah Bandar Lampung dalam menanggulangi kegiatan ilegal pedagang kaki lima di Pasar Bambu Kuning. Menggunakan pendekatan normatif dengan memanfaatkan data sekunder disimpulkan bahwa penggunaan sarana penal atau (hukum) pidana dalam suatu kebijakan merupakan cara untuk mengefektifkan pelaksanaan peraturan. Selain itu, dapat disimpulkan bahwa adanya pidana dalam suatu peraturan hanya akan efektif apabila 1) pidana itu sungguh-sungguh mencegah; 2) pidana itu tidak menyebabkan timbulnya keadaan yang lebih berbahaya atau merugikan daripada yang akan terjadi apabila pidana itu tidak dikenakan; dan 3) tidak ada pidana lain yang dapat mencegah secara efektif dengan bahaya atau kerugian yang lebih kecil. Pemberian sanksi pidana dalam suatu peraturan, berfungsi mencegah terjadinya kejahatan, dan selain itu jika kejahatan telah terjadi, maka fungsi ketentuan pidana adalah untuk memberi efek jera bagi pelakunya.

Kata kunci : Politik Hukum, Hukum Pidana dan Pedagang Kaki Lima 


\section{A. Pendahuluan}

Dalam kehidupan sehari-hari, sering terjadi kejahatan di dalam masyarakat. Kejahatan atau tindak kriminal merupakan salah satu bentuk dari "perilaku menyimpang"1 yang selalu ada dan melekat pada tiap bentuk masyarakat; tidak ada masyarakat yang sepi dari kejahatan. Menurut Saparinah Sadli perilaku menyimpang itu merupakan suatu ancaman yang nyata atau ancaman terhadap norma-norma sosial yang mendasari kehidupan atau keteraturan sosial; dapat menimbulkan ketegangan individual maupun ketegangan-ketegangan sosial; dan merupakan ancaman riil atau potensiil bagi berlangsungnya ketertiban sosial. ${ }^{2}$ Dengan demikian, kejahatan di samping merupakan masalah kemanusiaan, ia juga merupakan masalah sosial. $^{3}$ Bahkan menurut Benedict S. Alpen merupakan "the oldest social problem". 4

Terhadap masalah kemanusiaan dan masalah kemasyarakatan yang tertua ini telah banyak usaha-usaha penanggulangan yang dilakukan dalam berbagai cara. Salah satu usaha pencegahan dan pengendalian kejahatan itu ialah menggunakan hukum pidana dengan sanksinya yang berupa pidana.

Namun demikian, usaha ini pun masih sering dipersoalkan. Menurut Herbert L. Packer, usaha pengendalian perbuatan anti sosial dengan mengenakan pidana pada seseorang yang bersalah melanggar peraturan pidana merupakan "suatu problem sosial yang memunyai dimensi hukum yang penting". 5 Maksud perkataan ini adalah apakah penerapan sanksi pidana itu sudah tepat dalam prakteknya.

Penggunaan upaya hukum, termasuk hukum pidana, sebagai salah satu upaya untuk mengatasi masalah sosial termasuk dalam bidang kebijakan penegakan hukum. Karena tujuannya adalah untuk mencapai kesejahteraan masyarakat pada umumnya, maka kebijakan penegakan hukum itu pun termasuk dalam bidang kebijakan sosial, yaitu segala usaha yang rasional untuk mencapai kesejahteraan masyarakat. Sebagai suatu masalah yang termasuk masalah kebijakan, maka penggunaan (hukum) pidana sebenarnya tidak merupakan suatu keharusan. Akan tetapi merupakan alternatif yang

1 Saparinah. Sadli, Persepsi Sosial Mengenai Perilaku Menyimpang, (1996), hlm. 56 merumuskan "perilaku menyimpang" sebagai "tingkah laku yang dinilai menyimpang dan aturan-aturan normatif yang berlaku".

${ }^{2}$ Ibid, hlm. 25-26.

3 M. Ancel, Social Defence, 1995, hlm. 99 menyebutkan sebagai "a human and social problem".

${ }^{4}$ Benedict A. Alper, Changing Concept of Crime And Criminal Policy, UNAFEI No. 6/1993, hlm. 85.

${ }^{5}$ H.L Packer, The Limits of Criminal Sanction, (1998), hlm. 3. 
dapat ditempuh untuk mengefektifkan hukum dan peraturan, antara lain agar hukum tersebut lebih diperhatikan oleh masyarakat. ${ }^{6}$

Di dalam praktek pembuatan perundang-undangan, sering dijumpai adanya peraturan non-pidana yang memuat ketentuan pidana. Sebagai contoh di dalam Peraturan Daerah. Salah satu Perda yang memuat ketentuan pidana didalamnya adalah Perda Nomor 8 Tahun 2000 tentang Pembinaan Umum, Ketertiban, Keamanan, Kebersihan, Kesehatan dan Keapikan dalam Wilayah Kota Bandar Lampung.

Perda ini memuat ketentuan pidana bagi pelanggar ketentuan yang diatur dalam Perda di dalam Pasal 26 yang menentukan bahwa:

1. barang siapa yang melanggar ketentuan-ketentuan atau tidak mengindahkan larangan-larangan yang diberikan dan atau tidak menaati kewajiban dalam Peraturan Daerah ini diancam dengan pidana kurungan selama-lamanya 6 (enam) bulan dan atau denda sebanyak-banyaknya Rp.5.000.000,- (lima juta rupiah) kecuali ditentukan lain oleh peraturan perundang-undangan yang berlaku;

2. jika waktu melakukan pelanggaran belum lampau 1 (satu) tahun sejak pelanggar dihukum dengan keputusan yang tidak dapat diubah lagi karena perbuatan yang sama maka hukuman tersebut pada ayat (1) ini dapat digandakan;

3. ancaman pidana sebagaimana dimaksud Pasal ini berlaku juga bagi aparat atau petugas pelaksana; dan

4. dikecualikan dari ketentuan Pasal 26 ayat (1) Peraturan Daerah ini dan berlaku hanya bersifat himbauan adalah ketentuan yang diatur dalam Pasal 2 ayat (2), Pasal 3 huruf b dan d, dan Pasal 14 ayat (3).

Adapun ketentuan dan larangan-larangan yang menimbulkan sanksi pidana sebagaimana dimaksud dalam Pasal 26 di atas antara lain:

1. setiap orang wajib memelihara ketertiban, keamanan, kebersihan, keindahan, keapikan, kesehatan, dan kelestarian lingkungannya (Pasal 2 ayat (1) Perda 8/2000);

2. setiap pedagang wajib membungkus sampah yang ditimbulkannya dan menyerahkan langsung kepada petugas kebersihan atau meletakkan langsung pada tempat-tempat yang telah ditentukan (Pasal 5 Perda $8 / 2000)$

3. setiap warga kota berkawajiban untuk menjaga tanaman penghijauan yang ada di sekitar tempat tinggalnya (Pasal 11 Perda 8/2000);

4. dilarang membuang sampah atau suatu benda di jalan, trotoar, gang-gang dalam pasar, tepi pantai, sungai, sumber air, parit/saluran air, selokan air,

\footnotetext{
${ }^{6}$ Muladi dan Barda Nawawi Arief, Teori-teori dan Kebijakan Pidana, (Bandung: Alumni, 2005), hlm. 149.
} 
taman, lapangan dan tanah kosong milik orang lain, atau tempat-tempat umum lainnya (Pasal 15 ayat (1) Perda 8/2000); dan

5. dilarang mempergunakan jalan umum atau trotoar atau pada teras depan bangunan pertokoan/bangunan pasar yang menghadap pada jalan umum untuk pedagang kaki lima atau usaha lainnya, kecuali pada tempat-tempat yang ditentukan/ditunjukan oleh Walikota (Pasal 16 ayat (1) Perda 8/2000).

Berdasarkan ketentuan dan larangan di atas, dapat diketahui bahwa ketentuan-ketentuan yang diberi sanksi pidana sebagaimana ditentukan dalam Pasal 26 merupakan peristiwa-peristiwa non pidana. Misalnya tentang PKL yang diatur dalam Pasal 16 ayat (1). Ketentuan pidana yang diterapkan pada PKL ini ditujukan agar para PKL tidak melanggar larangan yang telah ditetapkan. Akan tetapi, apakah pendekatan pemberian pidana ini sudah tepat, hal itu masih perlu dikaji lagi. Hal ini juga berlaku pada peraturan lain pada umumnya, harus dikaji, apakah pemberian ketentuan pidana pada peraturan non pidana adalah tepat.

Penanganan permasalahan terhadap pedagang kaki lima perlukah dilakukan dengan mengenakan sanksi? Seperti diketahui bahwa penetapan sanksi dalam Perda akan berkombinasi antara sanksi pidana dan sanksi administrasi. Ketentuan Pasal 71 UU No. 22 Tahun 1999 tentang peraturan daerah, menetapkan :

1. peraturan daerah dapat memuat ketentuan tentang pembebanan biaya paksaan penegakan hukum, seluruhnya atau sebagian atas biaya pelanggar (sanksi administrasi); dan

2. peraturan daerah dapat memuat ancaman pidana kurungan paling lama enam bulan atau denda sebanyak-banyaknya Rp.5.000.000,00 (lima juta rupiah) dengan atau tidak merampas barang tertentu untuk daerah, kecuali jika ditentukan lain dalam peraturan perundang-undangan.

Ketentuan Pasal 71 ayat (1) menjadi dasar hukum pengaturan sanksi administrasi, tujuan utamanya adalah menyelesaikan pelanggaran (reparatory). Sanksi administrasi dapat diterapkan langsung oleh pemerintah. Oleh sebab itu, peraturan daerah harus merumuskan secara lengkap dasar hukum, jenis sanksi, prosedur, dan pejabat yang berwenang menerapkan sanksi administrasi. Hal ini berbeda dengan sanksi pidana, karena perancang perda hanya cukup merumuskan dalam perda, sedang penerapan sanksinya dilakukan melalui prosedur KUHAP. ${ }^{7}$

Berdasarkan uraian di atas, penulis tertarik untuk meneliti permasalahan mengenai "Bagaimanakah pemberian sanksi pidana pada peraturan perundang-undangan mengenai pedagang kaki lima di Bandar

\footnotetext{
${ }^{7}$ www.Google.com/wikipedia
} 
Lampung, apakah sudah merupakan politik kebijakan pidana yang tepat atau belum?".

\section{B. Pembahasan}

\section{Penanggulangan Kejahatan dengan (Hukum) Pidana}

Penanggulangan kejahatan dengan menggunakan (hukum) pidana merupakan cara yang paling tua, setua peradaban manusia itu sendiri. Ada pula yang menyebutnya sebagai "older philosophy of crime control". ${ }^{8}$ Dilihat sebagai suatu masalah kebijakan, maka ada yang mempermasalahkan apakah perlu kejahatan itu ditanggulangi, dicegah atau dikendalikan, dengan menggunakan sanksi pidana.

Ada sementara pendapat bahwa terhadap pelaku kejahatan atau para pelanggar hukum pada umumnya tidak perlu dikenakan pidana. Menurut pendapat ini pidana merupakan "peninggalan dari kebiadaban kita masa lalu" (a vestige of our savage past) ${ }^{9}$ yang seharusnya dihindari. Pendapat ini tampaknya di dasarkan pada pandangan bahwa pidana merupakan tindakan perlakuan atau pengenaan penderitaan yang kejam.

Memang, sejarah hukum pidana menurut Bassiouni, penuh dengan gambaran-gambaran mengenai perlakuan yang oleh ukuran-ukuran sekarang dipandang kejam dan melampaui batas. Dikemukakan selanjutnya bahwa gerakan pembaharuan pidana di Eropa Kontinental dan di Inggris melakukan reaksi humanistis yang menentang kekejaman pidana. ${ }^{10}$ Atas dasar pandangan yang demikian pulalah kiranya, ada pendapat bahwa teori retributive atau teori pembalasan dalam hal pemidanaan merupakan "a relic of barbarism". ${ }^{11}$

Dasar pemikiran lainnya ialah adanya paham determinisme yang menyatakan bahwa orang tidak memunyai kehendak bebas dalam melakukan suatu perbuatan karena dipengaruhi oleh watak pribadinya, faktor-faktor biologis maupun faktor lingkungan kemasyarakatannya. Dengan demikian, kejahatan sebenarnya merupakan manifestasi dari keadaan jiwa seseorang yang abnormal. Oleh karena itu, si pelaku kejahatan tidak dapat dipersalahkan atas perbuatannya dan tidak dapat dikenakan pidana. Karena seorang penjahat merupakan jenis manusia khusus yang memiliki ketidaknormalan organik dan mental, maka bukan pidana yang seharusnya

\footnotetext{
${ }^{8}$ Gene Kassebaum, Delinquency and Social Policy, (1994), hlm. 93.

${ }^{9}$ H.L. Packer, loc. cit.

${ }^{10}$ M. Cherif Bassiouni, Substantive Criminal Law, (1998), hlm. 86 dengan menunjuk B. Malinowski, Crime and Custom in Savage Society, (1994); dan E. Hoebel, The Law of Primitive Man, (1991).

${ }^{11}$ Smith \& Hogan, Criminal Law, 4th. ed., (1998), hlm. 6.
} 
dikenakan kepadanya, tetapi yang diperlukan adalah tindakan-tindakan perawatan yang bertujuan memperbaiki. ${ }^{12}$

Pandangan determinisme inilah yang menjadi ide dasar dan sangat mempengaruhi aliran positif di dalam kriminologi dengan tokohnya antara lain Lombroso, Garofalo, dan Fem. Menurut Alf Ross, pandangan inilah yang kemudian berlanjut pada gerakan modern mengenai "the campaign against punishment" (kampanye anti pidana). ${ }^{13}$

Kampanye anti pidana ini masih terdengar di abad XX ini dengan slogan barunya yang terkenal "the struggle against punishment" atau "Abolition of punishment". Antara lain, dikemukakan oleh seorang ahli psychiatri forensic dan kriminolog Swedia bernama Olof Kinberg yang pada tahun 1946 mengeluarkan tulisan berjudul "Punishment and Impunity" dan pada tahun 1948 berjudul "Le Droit de Punir". Menurut Kinberg, kejahatan pada umumnya merupakan perwujudan dari ketidaknormalan atau ketidakmatangan si pelanggar (the expression of an offender's abnormality or immaturity) yang lebih memerlukan tindakan perawatan (treatment) daripada pidana. ${ }^{14}$

Seorang kriminolog lainnya, bernama Karl Menninger menerbitkan pula sebuah buku pada tahun 1966 yang berjudul "The Crime of Punishment". Menurut Menninger, "sikap memidana" (punitive attitude) harus diganti dengan "sikap mengobati" (therapeutic attitude). ${ }^{15}$

Ide penghapusan pidana itu dikemukakan pula oleh Filippo Gramatica, seorang tokoh ekstrim dari aliran "defense sociale" yang merupakan perkembangan lebih lanjut dari aliran modern. Pada tahun 1947, tulisan-tulisan dan ceramah-ceramahnya dipublikasikan di dalam "Rivista di difesa sociale" yang salah satu tulisannya berjudul "La lotta contra la pena" (The fight against punishment). Menurut Gramatica, "hukum perlindungan sosial" harus menggantikan hukum pidana yang ada sekarang.

Tujuan utama dari hukum perlindungan sosial adalah mengintegrasikan individu ke dalam tertib sosial dan bukan pemidanaan terhadap perbuatannya. Hukum perlindungan sosial menyaratkan penghapusan pertanggungjawaban pidana (kesalahan) dan digantikan tempatnya oleh pandangan tentang perbuatan anti sosial. ${ }^{16}$ Jadi, pada

\footnotetext{
${ }^{12}$ Ibid.

${ }^{13}$ Alf Ross, On Guilt Responsibility and Punishment, (1995), hlm. 67 dst. dan 101.

${ }^{14}$ Pandangan Kinberg di Swedia ini kemudian dilanjutkan oleh J. Andenaes, The General Part of the Criminal Law of Norway, (1995), hlm. 86 dan 91.

${ }^{15}$ Stanley E. Grupp, Theories of Punishment, (1991), hlm. 250.

${ }^{16}$ Marc Ancel, Social Defence, (1995), hlm. 73 - 74; Lihat pula Sudarto, Suatu Dilema dalam Pembaharuan Sistem Pidana Indonesia, cetakan ke-2, (1996), hlm. 30; Muladi dan Barda Nawawi Arief, Pidana dan Pemidanaan, (1982), hlm. 24 - 25.
} 
prinsipnya ajaran Gramatica menolak konsepsi-konsepsi mengenai tindak pidana, penjahat, dan pidana.

Pandangan atau alam pikiran untuk menghapuskan pidana dan hukum pidana seperti dikemukakan di atas menurut Roeslan Saleh adalah keliru. Beliau mengemukakan tiga alasan yang cukup panjang mengenai masih perlunya pidana dan hukum pidana. ${ }^{17}$ Adapun intinya adalah sebagai berikut:

a. perlu tidaknya hukum pidana tidak terletak pada persoalan tujuan-tujuan yang hendak dicapai, tetapi terletak pada persoalan seberapa jauh untuk mencapai tujuan itu boleh menggunakan paksaan; persoalannya bukan terletak pada hasil yang akan dicapai, tetapi dalam pertimbangan antara nilai dari hasil itu dan nilai dari batas-batas kebebasan pribadi masingmasing;

b. ada usaha-usaha perbaikan atau perawatan yang tidak memunyai arti sama sekali bagi si terhukum; dan di samping itu, harus tetap ada suatu reaksi atas pelanggaran-pelanggaran norma yang telah dilakukannya itu dan tidaklah dapat dibiarkan begitu saja; dan

c. pengaruh pidana atau hukum pidana bukan semata-mata ditujukan pada si penjahat, tetapi juga untuk mempengaruhi orang yang tidak jahat yaitu warga masyarakat yang menaati norma-norma masyarakat.

Menurut Barda Nawawi Arief sebagaimana dikutip Teguh Prasetya dan Abdul Halim Barkatullah. ${ }^{18}$ Bila dihubungkan dengan pengertian kejahatan (kriminal) sebagai suatu konsep yang relatif, dinamis, serta bergantung pada ruang dan waktu maka sumber bahan dalam kebijakan kriminalisasi harus di dasarkan pada hal-hal sebagai berikut :

a. masukan berbagai penemuan ilmiah;

b. masukan dari beberapa hasil penelitian dan pengkajian mengenai perkembangan delik-delik khusus dalam masyarakat dan perkembangan iptek;

c. masukan dari pengkajian dan pengamatan bentuk-bentuk serta dimensi baru kejahatan dalam pertemuan/kongres internasional;

d. Masukan dari konvensi internasional; dan

e. Masukan dari pengkajian perbandingan berbagai KUHP asing.

Sesuai dengan prinsip subsidaritas maka dalam menentukan perbuatan pidana, harus selektif dalam memproses perkara, dan selektif pula dalam memilih ancaman pidana.

\footnotetext{
17 Roeslan Saleh, Mencari Azas-azas Umum yang Sesuai untuk Hukum Pidana Nasional, Kumpulan bahan upgrading hukum pidana, (1995), jilid 2, hlm. 15 - 16. Lihat pula Barda Nawawi Arief, Masalah Pemidanaan Sehubungan dengan Perkembangan Kriminalitas dan Perkembangan Delik-Delik Khusus dalam Masyarakat Modern, BPHN, (Dep. Kehakiman, 1980) hlm. 14-16.

${ }^{18}$ Teguh Prasetya dan Abdul Hlmim barkatullah, Politik Hukum Pidana Kajian Kriminalisasi dan Dekriminalisasi, (Yogyakarta: Pustaka Pelajar, 2005), hlm 46,139.
} 
Apabila bisa diselesaikan dengan cara lain, sebaiknya tidak perlu menggunakan hukum pidana (ultimum remidium) dan apabila dengan pidana percobaan atau denda dipandang cukup, pidana penjara harus dihindari. Jika sekiranya terpaksa menggunakan pidana penjara, harus dipilih lama pidana paling ringan dan memberi manfaat kepada terdakwa.

Memperhatikan alasan-alasan di atas, maka tampaknya Roeslan Saleh tetap mempertahankan adanya pidana dan hukum pidana dilihat dari sudut politik kriminil dan dari sudut tujuan, fungsi, dan pengaruh dari (hukum) pidana itu sendiri. Istilah yang digunakan oleh beliau sendiri ialah "masih adanya dasar susila dari hukum pidana".

Menurut Alf Ross, ide-ide dasar dari "kampanye anti pidana" tidak dapat dipertahankan. Adapun alasan yang dikemukakannya ialah: ${ }^{19}$

a. Merupakan asumsi yang tidak benar bahwa pencelaan moral dan pidana (yang merupakan perwujudan dari pencelaan moral itu) adalah bertentangan atau tidak cocok dengan pemikiran ilmiah yang di dasarkan pada determinisme. Hal ini merupakan suatu kekeliruan yang disebabkan oleh pandangan filsafat yang kacau.

b. Merupakan asumsi yang tidak benar, bahwa pencelaan moral dan pidana tidak ada hubungannya dengan tujuan preventif dari pidana; hal ini merupakan suatu kekeliruan yang timbul dari kebingungan konseptual bahwa 'pencegahan' (prevention) dan 'pembalasan' (retribution) merupakan tujuan-tujuan dari pidana.

c. Merupakan asumsi yang tidak benar, bahwa tidak mungkin merumuskan atau menerapkan suatu kriteria mengenai pertanggungjawaban mental; hal ini merupakan suatu kekeliruan yang berasal dari tuntutan ilmu pengetahuan yang dilebih-lebihkan yang diperlukan untuk membuat penilaian moral dan penilaian hukum.

Marc Ancel sebagai penganut aliran defense sociale yang lebih moderat (alirannya disebut 'defense sociale nouvelle') juga mengemukakan bahwa kesimpulan yang dilakukan Gramatica agak terburu-buru dan dilebihlebihkan. Menurut Marc Ancel tiap masyarakat mensyaratkan adanya tertib sosial, yaitu seperangkat peraturan-peraturan yang tidak hanya sesuai dengan kebutuhan untuk kehidupan bersama, tetapi juga sesuai dengan aspirasiaspirasi warga masyarakat pada umumnya. Oleh karena itu, peranan yang besar dari hukum pidana merupakan kebutuhan yang tidak dapat dielakan bagi suatu sistem hukum.

Perlindungan individu maupun masyarakat bergantung kepada perumusan yang tepat mengenai hukum pidana dan hal ini tidak kurang pentingnya dari kehidupan masyarakat itu sendiri. Oleh karena itu, sistem hukum pidana, tindak pidana, penilaian hakim terhadap si pelanggar dalam

\footnotetext{
${ }^{19}$ Alf Ross, Op.Cit, hlm. 98 - 99.
} 
hubungannya dengan hukum secara murni maupun pidana merupakan lembaga-lembaga (institusi) yang harus tetap dipertahankan. Hanya saja, dalam menggunakan sistem hukum pidana Marc Ancel menolak penggunaan fiksi-fiksi yuridis dan teknik-teknik yuridis yang terlepas dari kenyataan sosial.

Marc Ancel menolak pandangan aliran klasik dan neoklasik yang memperlakukan kejahatan sebagai konsepsi hukum yang murni dan sanksi pidana merupakan konsekuensi yang diperlukan menurut hukum terhadap pelanggaran tata/ketertiban yang ada; dan juga menolak bahwa tujuan pidana atau sanksi-sanksi lain adalah "pembaharuan kembali tertib hukum tersebut secara abstrak" (the abstract restoradonof that legal order).

Kejahatan sebagai "a human and social problem", menurut Marc Ancel, tidak begitu saja mudah dipaksa untuk dimasukan ke dalam perumusan suatu peraturan undang-undang. Ini tidak berarti bahwa Hakim pidana tidak memutus berdasar undang-undang dan harus menolak pidana. Diakuinya bahwa hal ini, penerapan pidana berdasar undang-undang, merupakan bagian essensiil dari tugas seorang hakim, tetapi Ancel menyangkal bahwa problem kemanusiaan dan problem kemasyarakatan yang ditimbulkan oleh suatu tindak pidana dapat diselesaikan atau dipecahkan secara keseluruhan oleh bekerjanya suatu konsepsi keadilan distributif secara abstrak. ${ }^{20}$

Packer juga membicarakan masalah pidana ini di dalam bukunya "The Limits of Criminal Sanction", akhirnya menyimpulkan antara lain sebagai berikut: ${ }^{21}$

a. sanksi pidana sangatlah diperlukan; kita tidak dapat hidup, sekarang maupun di masa yang akan datang, tanpa pidana. (The criminal sanction is indispensable; we could not, now or in the foreseeable future, get along without it);

b. sanksi pidana merupakan alat atau sarana terbaik yang tersedia, yang kita miliki untuk menghadapi kejahatan-kejahatan atau bahaya besar dan segera, serta untuk menghadapi ancaman-ancaman dari bahaya. (The criminal sanction is the best available device we have for dealing with gross and immediate harms and threats of harm); dan

c. sanksi pidana suatu ketika merupakan 'penjamin yang utama/terbaik' dan suatu ketika merupakan 'pengancam yang utama' dari kebebasan manusia. Ia merupakan penjamin apabila digunakan secara hemat-cermat dan secara manusiawi; ia merupakan pengancam, apabila digunakan secara sembarangan dan secara paksa. (The criminal sanction is at once prime guarantor and prime threatener of human freedom. Used providently and

\footnotetext{
${ }^{20}$ Marc Ancel, Op.Cit, hlm. 74 - 76; lihat pula Sudarto, Op.Cit, hlm. 30.

${ }^{21}$ H.L. Packer, Op.Cit, hlm. 364 - 366.
} 
humanely, it is guarantor; used indiscriminately and coercively, it is threatener).

Menurut Teguh Prasetyo dan Abdul Halim Barkatullah kebijakan hukum pidana terdiri atas beberapa tahap yakni: ${ }^{22}$

a. tahap formulasi atau kebijakan legislatif dapat dikatakan sebagai tahap perencanaan dan perumusan peraturan perundang-undangan pidana;

b. tahap aplikasi atau kebijakan yudikatif merupakan perundang-undangan pidana yang telah dilanggar; dan

c. tahap eksekusi atau kebijakan administratif adalah tahap pelaksanaan putusan pengadilan atas perbuatan pidana yang telah memperoleh kekuatan hukum tetap.

Tahap formulasi atau kebijakan legislatif merupakan tahap awal yang paling strategis dari keseluruhan perencanaan proses fungsionalisasi hukum pidana.

Sedangkan menurut Barda Nawawi Tahap formulasi atau kebijakan legislatif menjadi dasar, landasan, dan pedoman bagi tahap-tahap fungsionalisasi atau operasionalisasi hukum pidana berikutnya yaitu tahap aplikasi dan tahap eksekusi. ${ }^{23}$ Oleh karena itu, perbuatan pidana harus telah diatur terlebih dahulu dalam suatu undang-undang sebelum perbuatan pidana dilakukan dikenal dengan Asas Legalitas (asas Nullum delictum nulla poena sinepraevia sine lege poenali secara singkat nullum crimen sine lege berarti tindak pidana tanpa undang-undang dan nulla poene sine lege berarti tidak ada pidana tanpa undang-undang.

Sehubungan dengan masalah di atas, tepat kiranya apa yang dikemukakan oleh Johannes Andenaes bahwa pertanyaan tentang pembatasan konsep pidana tidak hanya merupakan masalah hukum, tetapi juga masalah moral. Dari sudut pandang praktek, harus diakui bahwa pemikiran tentang kesalahan dan pidana sudah menjadi bagian dari pikiran publik. Legislatif harus mempertimbangkan kenyataan ini. ${ }^{24}$

Berdasarkan uraian di atas dapat diketahui bahwa penggunaan ketentuan pidana di dalam peraturan perundang-undangan masih dapat diterima dalam kebijakan pidana sekarang ini. Adanya pidana tidak hanya ditujukan untuk memberi hukuman terhadap pelaku, tetapi lebih penting dari itu adalah sebagai kebijakan pencegahan terjadinya kejahatan (menanggulangi kejahatan).

\footnotetext{
${ }^{22}$ Teguh Prasetyo, Abdul Hlmim Barkatullah, Op.Cit, hlm 22

${ }^{23}$ Barda Nawawi Arief, Bunga Rampai Hukum Pidana, (Bandung: Alumni, 1992), hlm 157158

${ }^{24}$ Johannes Andenaes, Op.Cit, hlm. 92 - 93.
} 


\section{Kebijakan Menggunakan Hukum Pidana}

Digunakannya hukum pidana di Indonesia sebagai sarana untuk menanggulangi kejahatan tampaknya tidak menjadi persoalan. Hal ini terlihat dari praktek perundang-undangan selama ini yang menunjukkan bahwa penggunaan hukum pidana merupakan bagian dari kebijakan atau politik hukum yang dianut di Indonesia. Penggunaan hukum pidana dianggap sebagai hal yang wajar dan normal, seolah-olah eksistensinya tidak lagi dipersoalkan. Yang menjadi masalah ialah garis-garis kebijakan atau pendekatan bagaimanakah yang sebaiknya ditempuh dalam menggunakan hukum pidana itu?

Sudarto pernah mengemukakan bahwa apabila hukum pidana hendak digunakan hendaknya dilihat dalam hubungan keseluruhan politik kriminil atau "social defence planning" yang inipun harus merupakan bagian integral dari rencana pembangunan nasional. ${ }^{25}$

Politik kriminil ialah pengaturan atau penyusunan secara rasional usaha-usaha pengendalian kejahatan oleh masyarakat. ${ }^{26}$ Tujuan akhir dari kebijakan kriminil ialah "perlindungan masyarakat" untuk mencapai tujuan utama yang sering disebut dengan berbagai istilah misalnya "kebahagiaan warga masyarakat/penduduk" (happiness of the citizens); "kehidupan kultural yang sehat dan menyegarkan" (a wholesome and cultural living), "kesejahteraan masyarakat" (social welfare), atau untuk mencapai "keseimbangan" (equality). ${ }^{27}$ Dengan memperhatikan tujuan-tujuan tersebut, maka wajarlah apabila dikatakan bahwa politik kriminal merupakan bagian integral dari rencana pembangunan nasional.

\section{Pendekatan Integral Antara Kebijakan Penal dan Non-Penal}

Usaha-usaha yang rasional untuk mengendalikan atau menanggulangi kejahatan (politik kriminil) sudah barang tentu tidak hanya dengan menggunakan sarana "penal" (hukum pidana), tetapi dapat juga dengan menggunakan sarana-sarana yang "non-penal".

Usaha-usaha nonpenal ini misalnya penyantunan dan pendidikan sosial dalam rangka mengembangkan tanggung jawab sosial warga masyarakat; penggarapan kesehatan jiwa masyarakat melalui pendidikan moral, agama; peningkatan usaha-usaha kesejahteraan anak dan remaja;

\footnotetext{
${ }^{25}$ Sudarto, S.H., Prof., Hukum dan Hukum Pidana, (1997), hlm. 104. Lihat pula W. Clifford, Reform in Criminal Justice in Asia and the Far East, Resource Material Series No. 6, UNAFEI, 1993, page. 7. Demikian pula G.P. Hoefnagels, "The Other Side of Criminology", (1993), hlm. 57.

26 Marc Ancel, Op.Cit, h. 209, Sudarto, Kapita Selekta Hukum Pidana, (1981), hlm. 113-114.

${ }^{27}$ Barda N. Arief, Masalah Pemidanaan Sehubungan dengan Perkembangan Kriminalitas dan Perkembangan Delik-Delik Khusus Dalam Masyarakat Modern, BPHN. (1980), hlm. 8.
} 
kegiatan patroli dan pengawasan lainnya secara berkelanjutan oleh polisi dan aparat keamanan lainnya, dan sebagainya.

Usaha-usaha nonpenal ini dapat meliputi bidang yang sangat luas sekali di seluruh sektor kebijakan sosial. Tujuan utama dari usaha-usaha non-penal itu adalah memperbaiki kondisi-kondisi sosial tertentu. Namun, secara tidak langsung memunyai pengaruh preventif terhadap kejahatan. Dengan demikian, dilihat dari sudut politik kriminil, keseluruhan kegiatan preventif yang nonpenal itu sebenarnya mempunyai kedudukan yang sangat strategis, memegang posisi kunci yang harus diintensifkan dan diefektifkan.

Kegagalan dalam menggarap posisi strategis ini justru akan berakibat sangat fatal bagi usaha penanggulangan kejahatan. Oleh karena itu, suatu kebijakan kriminil harus dapat mengintegrasikan dan mengharmonisasikan seluruh kegiatan preventif yang nonpenal itu ke dalam suatu sistem kegiatan negara yang teratur dan terpadu. Sehubungan dengan ini Radzinowics, menyatakan:

"Criminal policy must combine the various preventive activities and adjust them so, as to form a single comprehensive machine and finally coordinate the whole into an organized system of activity". ${ }^{28}$

Penegakan hukum dengan sarana penal merupakan salah satu aspek saja dari usaha masyarakat menanggulangi kejahatan. Di samping itu, masih dikenal usaha masyarakat menanggulangi kejahatan melalui sarana nonpenal. Usaha nonpenal dalam menanggulangi kejahatan sangat berkaitan erat dengan usaha penal. Upaya nonpenal ini dengan sendirinya akan sangat menunjang penyelenggaraan peradilan pidana dalam mencapai tujuannya. Pencegahan atau atau menanggulangi kejahatan harus dilakukan pendekatan integral yaitu antara sarana penal dan non-penal.

Menurut M. Hamdan, upaya penanggulangan yang merupakan bagian dari kebijakan sosial pada hakikatnya juga merupakan bagian integral dari upaya perlindungan masyarakat (social defence) yang dapat ditempuh dengan 2 jalur, yaitu: ${ }^{29}$

a. jalur penal, yaitu dengan menerapkan hukum pidana (criminal law application); dan

b. jalur nonpenal, yaitu dengan cara:

1) pencegahan tanpa pidana (prevention without punisment), termasuk di dalamnya penerapan sanksi administratif dan sanksi perdata; dan

2) mempengaruhi pandangan masyarakat mengenai kejahatan dan pembinaan lewat media massa (influencing views of society on crime and punishment).

${ }^{28}$ Dikutip dari Karl O. Christiansen, Some Consideration on the Possibility of a Rational Criminal Policy, Resource Material Series, No. 7, 1994, UNAFEI, Tokyo, hlm. 74.

${ }^{29}$ M. Hamdan, Politik Hukum Pidana. (Jakarta: Penerbit PT Raja Grafindo Persada, 1999). 
Secara sederhana dapatlah dibedakan, bahwa upaya penanggulangan kejahatan lewat jalur "penal" lebih menitikberatkan pada sifat "repressive" (penindasan/pemberantasan/penumpasan) sesudah kejahatan terjadi, sedangkan jalur "nonpenal" lebih menitikberatkan pada sifat "preventive" (pencegahan/penangkalan/pengendalian) sebelum kejahatan terjadi.

Dengan demikian, masalah utamanya adalah mengintegrasikan dan mengharmonisasikan kegiatan atau kebijakan nonpenal dan penal itu ke arah penekanan atau pengurangan faktor-faktor potensial untuk tumbuh suburnya kejahatan. Dengan pendekatan kebijakan yang integral inilah diharapkan "social defence planning" benar-benar dapat berhasil. Dengan demikian, diharapkan pula tercapainya hakikat tujuan kebijakan sosial yang tertuang dalam rencana pembangunan nasional yaitu "kualitas lingkungan hidup yang sehat dan bermakna".

\section{Pendekatan Kebijakan dan Pendekatan Nilai dalam Penggunaan Hukum Pidana}

Dua masalah sentral dalam kebijakan kriminil dengan menggunakan sarana penal (hukum pidana) ialah masalah penentuan terhadap; 1) perbuatan apa yang seharusnya dijadikan tindak pidana; dan 2) sanksi apa yang sebaiknya digunakan atau dikenakan kepada si pelanggar.

Penganalisisan terhadap dua masalah sentral ini tidak dapat dilepaskan dari konsepsi bahwa kebijakan kriminil merupakan bagian integral dari kebijakan sosial. Ini berarti pemecahan masalah-masalah tersebut di atas harus pula diarahkan untuk mencapai tujuan-tujuan tertentu dari kebijakan sosial yang telah ditetapkan. Dengan demikian, kebijakan hukum pidana, termasuk pula kebijakan dalam menangani dua masalah sentral di atas, harus pula dilakukan dengan pendekatan yang berorientasi pada kebijakan (policy oriented approach).

Berdasar pendekatan yang berorientasi pada kebijakan sosial itulah Sudarto berpendapat bahwa dalam menghadapi masalah sentral yang pertama di atas, yang sering disebut masalah kriminalisasi, harus diperhatikan hal-hal yang pada intinya sebagai berikut ${ }^{30}$ :

a. penggunaan hukum pidana harus memperhatikan tujuan pembangunan nasional, yaitu mewujudkan masyarakat adil makmur yang merata materiil dan spiritual berdasarkan Pancasila; sehubungan dengan ini maka (penggunaan) hukum pidana bertujuan untuk menanggulangi kejahatan dan mengadakan pergerakan terhadap tindakan penanggulangan itu sendiri, demi kesejahteraan dan pengayoman masyarakat;

b. perbuatan yang diusahakan untuk dicegah atau ditanggulangi dengan hukum pidana harus merupakan "perbuatan yang tidak dikehendaki"

\footnotetext{
${ }^{30}$ Sudarto, Hukum dan HukumPidana, (Bandung: Alumni, 1997), hlm. 44 - 48.
} 
yaitu perbuatan yang mendatangkan kerugian (materiil dan atau spiritual) atas warga masyarakat;

c. penggunaan hukum pidana harus pula memperhitungkan prinsip "biaya dan hasil" (cost-benefit principle); dan

d. penggunaan hukum pidana harus pula memperhatikan kapasitas atau kemampuan daya kerja dari badan-badan penegak hukum, yaitu jangan sampai ada kelampauan beban tugas (overbelasting).

Menurut Bassiouni, keputusan untuk melakukan kriminalisasi dan dekriminalisasi harus di dasarkan pada faktor-faktor kebijakan tertentu yang mempertimbangkan bermacam faktor, termasuk: ${ }^{31}$

a. keseimbangan sarana-sarana yang digunakan dalam hubungannya dengan hasil yang dicari atau yang ingin dicapai; (the proportionality of the means, used in relationship to the outcome obtained);

b. analisis biaya terhadap hasil-hasil yang diperoleh dalam hubungannya dengan tujuan-tujuan yang dicari; (the cost analysis of the outcome in relationship to the objectives sought);

c. penilaian atau penaksiran tujuan-tujuan yang dicari itu dalam kaitannya dengan prioritas-prioritas lainnya dalam pengalokasian sumber-sumber tenaga manusia; (the appraisal of the objectives sought in relationship to other priorities in the allocation of resources of human power); dan

d. pengaruh sosial dan kriminalisasi dan dekriminalisasi yang berkenaan dengan (dipandang dari segi) pengaruh-pengaruhnya yang sekunder; (the social impact of criminalization and decriminalization in terms of its secondary effects).

Selanjutnya, dikemukakan bahwa problem dari pendekatan yang berorientasi pada kebijakan adalah kecenderungan untuk menjadi pragmatis dan kuantitatif serta tidak memberi kemungkinan untuk masuknya faktorfaktor yang subjektif, misalnya nilai-nilai, ke dalam proses pembuatan keputusan.

Namun demikian, pendekatan yang berorientasi pada kebijakan ini menurut Bassiouni seharusnya dipertimbangkan sebagai salah satu "scientific device" dan digunakan sebagai alternatif dari pendekatan yang secara emosional diorientasikan pada pertimbangan nilai (the emosionally laden value-judgment approach) yang kebanyakan diikuti oleh badan-badan legislatif.

Dikemukakan pula bahwa perkembangan dan "a policy oriented approach" ini lamban datangnya karena proses legislatif belum siap untuk pendekatan yang demikian. Masalahnya, antara lain terletak pada sumbersumber keuangan untuk melakukan orientasi ilmiah itu.

\footnotetext{
${ }^{31}$ M. Cherif Bassiouni, Op.Cit, hlm. 82.
} 
Kelambanan yang demikian ditambah dengan proses kriminalisasi yang berlangsung terus tanpa di dasarkan pada penilaian-penilaian yang teruji dan tanpa suatu evaluasi mengenai pengaruhnya terhadap keseluruhan sistem, mengakibatkan timbulnya; 1) Krisis kelebihan kriminalisasi (the crisis of overcriminalization); dan 2) Krisis pelampauan batas dari hukum pidana (the crisis of overreach of the criminal law).

Yang pertama mengenai banyaknya atau melimpahnya jumlah kejahatan dan perbuatan-perbuatan yang dikriminalisasikan, dan yang kedua mengenai usaha pengendalian perbuatan dengan tidak menggunakan sanksi pidana yang efektif. ${ }^{32}$

Pendekatan kebijakan seperti dikemukakan di atas jelas merupakan pendekatan yang rasional, karena karakteristik dari suatu politik kriminil yang rasional tidak lain daripada penerapan metode-metode yang rasional. ${ }^{33}$

Menurut Hoefnagels suatu politik kriminil harus rasional, kalau tidak demikian tidak sesuai dengan definisinya sebagai "a rational total of the responses to crime". Di samping itu, hal ini penting karena konsepsi mengenai kejahatan dan kekuasaan atau proses untuk melakukan kriminalisasi sering ditetapkan secara emosional. ${ }^{34}$

Menurut Sudarto dalam aliran klasik tentang pidana bersifat retributif dan represif terhadap tindak pidana. ${ }^{35}$ Aliran ini muncul pada abad XVIII berpaham indeterminisme mengenai kebebasan kehendak manusia yang menekankan pada perbuatan pelaku kejahatan sehingga dikehendaki hukum pidana perbuatan, karenanya sistem pidana dan pemidanaan menekankan terhadap perbuatan bukan pada pelakunya. Sistem pemidanaan ditetapkan secara pasti yakni penetapan sanksi dalam undang-undang tidak dipakai sistem peringanan atau pemberatan yang berhubungan dengan faktor usia, keadaan jiwa pelaku, kejahatan terdahulu, maupun keadaan khusus dari perbuatan kejahatan yang dilakukan, dengan demikian, tidak dipakai sistem individualisasi pidana.

Pada abad XIX lahirlah aliran modern yang mencari sebab kejahatan memakai metode ilmu alam mempengaruhi penjahat agar bisa diperbaiki. Kebebasan berkehendak manusia dipengaruhi oleh watak dan lingkungannya, sehingga tidak dapat dipersalahkan dan dipidana. Aliran ini menghendaki individualisasi pidana yang bertujuan resosialisasi terhadap pelaku kejahatan. Berdasarkan ide kedua aliran tersebut lahirlah ide

\footnotetext{
${ }^{32}$ Ibid., hlm. 82-84.

${ }^{33}$ Karl O. Christiansen, Op.Cit, hlm. 75.

${ }^{34}$ G.P. Hoefnagels, Op.Cit, hlm. 99.

35 Sudarto, Hukum Pidana dan Perkembangan Masyarakat Kajian Pembaharuan Hukum Pidana, (Bandung: Sinar Baru, 1985).
} 
individualisasi pidana yang memiliki beberapa karakteristik sebagai berikut: ${ }^{36}$

a. pertanggungjawaban pidana bersifat pribadi atu perseorangan (asas personal);

b. pidana hanya diberikan kepada orang yang bersalah (asas culpabilitas; tiada pidana tanpa kesalahan); dan

c. pidana harus disesuaikan dengan karakteristik dan kondisi pelaku ini berarti harus ada kelonggaran/fleksibilitas bagi hakim dalam memilih sanksi pidana (jenis maupun berat ringannya sanksi) dan harus ada kemungkinan modifikasi pidana (perubahan/penyesuaian) dalam pelaksanaannya.

Pendekatan yang rasional memang merupakan pendekatan yang seharusnya melekat pada setiap langkah kebijakan. Hal ini merupakan konsekuensi logis, karena seperti dikatakan oleh Sudarto, "dalam melaksanakan politik (kebijakan), orang mengadakan penilaian dan melakukan pemilihan dari sekian banyak alternatif yang dihadapi". ${ }^{37}$ Ini berarti, suatu politik kriminil dengan menggunakan kebijakan hukum pidana harus merupakan suatu usaha atau langkah-langkah yang dibuat dengan sengaja dan sadar.

Dengan demikian, memilih dan menetapkan (hukum) pidana sebagai sarana untuk menanggulangi kejahatan harus benar-benar telah memperhitungkan semua faktor yang dapat mendukung berfungsinya atau bekerjanya (hukum) pidana itu dalam kenyataannya. Jadi, diperlukan pula pendekatan yang fungsional; dan inipun merupakan pendekatan yang melekat (inherent) pada setiap kebijakan yang rasional.

Dalam penetapan pidana dalam suatu peraturan, perlu pula dipertimbangan bahwa hukum pidana harus dipertahankan sebagai salah satu sarana untuk "social defence". Pemilihan pada konsepsi perlindungan masyarakat ini membawa konsekuensi pada pendekatan yang rasional, seperti dikemukakan oleh Andenaes sebagai berikut: ${ }^{38}$

Apabila orang mendasarkan hukum pidana pada konsepsi perlindungan masyarakat/social defence, maka tugas selanjutnya adalah mengembangkannya serasional mungkin. Hasil-hasil maksimum harus dicapai dengan biaya yang minimum bagi masyarakat dan minimum penderitaan bagi individu. Dalam tugas demikian, orang harus mengandalkan pada hasil-hasil penelitian ilmiah mengenai sebab-sebab kejahatan dan efektivitas dari bermacam-macam sanksi).

\footnotetext{
${ }^{36}$ Muladi dan Barda Nawawi Arief, Op.Cit, hlm 43, 148.

${ }^{37}$ Sudarto, Op.Cit, hlm. 161.

${ }^{38}$ J. Andenaes, Op.Cit, hlm. 60.
} 
Dari apa yang dikemukakan Andenaes di atas jelas terlihat bahwa pendekatan kebijakan yang rasional berkaitan erat pula dengan pendekatan ekonomis dalam penggunaan sanksi pidana. Pendekatan ekonomis di sini tidak hanya dimaksudkan untuk mempertimbangkan antara biaya atau beban yang ditanggung masyarakat (dengan dibuat/digunakannya hukum pidana) dengan hasil yang ingin dicapai; tetapi juga dalam arti mempertimbangkan efektivitas dari sanksi pidana itu sendiri.

Sehubungan dengan hal ini, Ted Honderich berpendapat bahwa suatu pidana dapat disebut sebagai alat pencegah yang ekonomis (economical deterrents) apabila dipenuhi syarat-syarat sebagai berikut: ${ }^{39}$

a. pidana itu sungguh-sungguh mencegah;

b. pidana itu tidak menyebabkan timbulnya keadaan yang lebih berbahaya/merugikan daripada yang akan terjadi apabila pidana itu tidak dikenakan; dan

c. tidak ada pidana lain yang dapat mencegah secara efektif dengan bahaya/kerugian yang lebih kecil.

Segi lain yang perlu dikemukakan dari pendekatan kebijakan ialah yang berkaitan dengan nilai-nilai yang ingin dicapai atau dilindungi oleh hukum pidana. Menurut Bassiouni, tujuan-tujuan yang ingin dicapai oleh pidana pada umumnya terwujud dalam kepentingan-kepentingan sosial yang mengandung nilai-nilai tertentu yang perlu dilindungi. Kepentingankepentingan sosial tersebut menurut Bassiouni ialah:

a. pemeliharaan tertib masyarakat;

b. perlindungan warga masyarakat dari kejahatan, kerugian, atau bahayabahaya yang tidak dapat dibenarkan, yang dilakukan oleh orang lain;

c. memasyarakatkan kembali (resosialisasi) para pelanggar hukum; dan

d. memelihara atau mempertahankan integritas pandangan-pandangan dasar tertentu mengenai keadilan sosial, martabat kemanusiaan, dan keadilan individu.

Ditegaskan selanjutnya bahwa sanksi pidana harus disepadankan dengan kebutuhan untuk melindungi dan mempertahankan kepentingankepentingan ini. Pidana hanya dibenarkan apabila ada suatu kebutuhan yang berguna bagi masyarakat; suatu pidana yang tidak diperlukan, tidak dapat dibenarkan, dan berbahaya bagi masyarakat.

Selain itu, batas-batas sanksi pidana ditetapkan pula berdasar kepentingan-kepentingan ini dan nilai-nilai yang mewujudkannya. Berdasar pandangan yang demikian, maka menurut Bassiouni disiplin hukum pidana bukan hanya pragmatis, tetapi juga suatu disiplin yang berdasar dan

\footnotetext{
${ }^{39}$ Ted Hoderich, Punishment, (London: Penguin Books, 1971), hlm. 59.
} 
berorientasi pada nilai (not only pragmatic but also value-based and valueoriented). ${ }^{40}$

Dari uraian di atas, dapatlah disimpulkan bahwa menurut Bassiouni, dalam melakukan kebijakan hukum pidana diperlukan pendekatan yang berorientasi pada kebijakan (policy-oriented approach) yang lebih bersifat pragmatis dan juga pendekatan yang berorientasi pada nilai (value-judgment approach).

Namun demikian, antara pendekatan kebijakan dan pendekatan yang berorientasi pada nilai tidak boleh terlalu dilihat sebagai suatu "dichotomy", karena dalam pendekatan kebijakan sudah seharusnya juga dipertimbangkan faktor-faktor nilai.

Kebijakan kriminil tidak dapat dilepaskan sama sekali dari masalah nilai karena seperti dikatakan oleh Christiansen, "the conception of problem 'crime and punishment' is an essential part of the culture of any society" (konsepsi 'kejahatan dan pidana' merupakan bagian yang esensial dalam kehidupan masyarakat). ${ }^{41}$ Begitu pula menurut Clifford, "the very foundation of any criminal justice system consists of the phylosophy behind a given country" (Pondasi utama dari semua sistem hukum adalah filosofi dibelakangnya). ${ }^{42}$

Terlebih bagi Indonesia yang berdasarkan Pancasila dan garis kebijakan pembangunan nasionalnya bertujuan membentuk "Manusia Indonesia seutuhnya". Apabila pidana akan digunakan sebagai sarana untuk mencapai tujuan tersebut, maka pendekatan humanistis harus pula diperhatikan.

Hal ini penting, tidak hanya karena kejahatan itu pada hakikatnya merupakan masalah kemanusiaan (human problem), tetapi juga karena pada hakikatnya pidana itu sendiri mengandung unsur penderitaan yang dapat menyerang kepentingan atau nilai yang paling berharga bagi kehidupan manusia.

Pendekatan humanistis dalam penggunaan sanksi pidana, tidak hanya berarti bahwa pidana yang dikenakan kepada si pelanggar harus sesuai dengan nilai-nilai kemanusiaan yang beradab; tetapi juga harus dapat membangkitkan kesadaran si pelanggar akan nilai-nilai kemanusiaan dan nilai-nilai pergaulan hidup bermasyarakat.

Sehubungan dengan hal terakhir ini, patut kiranya dikemukakan konsepsi kebijakan pidana dari aliran social defence (the penal policy of social defence) menurut Marc Ancel yang bertolak pada konsepsi pertanggungjawaban yang bersifat pribadi.

\footnotetext{
${ }^{40}$ Cherif Bassiouni, Op.Cit, hlm. 78.

${ }^{41}$ Karl O. Christiansen,Op.Cit,. hlm. 78.

${ }^{42}$ W. Clifford,Op.Cit, hlm. 6.
} 
Hal ini perlu dikemukakan, karena istilah "perlindungan masyarakat" atau "social defence" yang dikaitkan dengan masalah rehabilitasi dan resosialisasi sudah sering digunakan di Indonesia seperti yang terlihat misalnya pada Seminar Kriminologi ke-3 tahun 1976 dan Simposium Pembaharuan Hukum Pidana Nasional pada tahun 1980 di Semarang.

Menurut Marc Ancel, pertanggungjawaban yang di dasarkan pada kebebasan individu merupakan kekuatan penggerak yang utama dari proses penyesuaian sosial (the main driving force of the process of social readaption). Diakui olehnya, bahwa masalah determinis medan indeterminisme merupakan problem filosofis yang berada di luar ruang lingkup kebijakan pidana dan hukum pidana. Akan tetapi, ditegaskan bahwa kebijakan pidana yang modern hampir selalu menyaratkan adanya kebebasan individu.

Tujuan utama dari setiap perlakuan readaptasi sosial harus diarahkan pada perbaikan terhadap penguasaan diri sendiri. Oleh karena itu, masalah pertanggungjawaban seharusnya tidak boleh diabaikan, malahan justru harus diperkenalkan kembali sebagai suatu pertanggungjawaban pribadi.

Reaksi terhadap perbuatan anti sosial justru harus dipusatkan pada konsepsi pertanggungjawaban pribadi. Pertanggungjawaban yang dimaksud oleh Marc Ancell berlainan dengan pandangan klasik yang mengartikannya sebagai "pertanggungajawaban moral secara murni" (the purely moral responsibility), dan berbeda pula dengan pandangan positivisme yang mengartikannya sebagai "pertanggungjawaban menurut hukum atau pertanggungjawaban objektif" (legal or objective view of responsibility).

Pertanggungjawaban pribadi (individual responsibility) menurut Marc Ancel menekankan pada perasaan kewajiban moral pada diri individu dan oleh karena itu mencoba untuk merangsang ide tanggung jawab/kewajiban sosial terhadap anggota masyarakat yang lain dan juga mendorongnya untuk menyadari moralitas sosial.

Pengertian yang demikian merupakan konsekuensi dari pandangan Marc Ancel yang melihat kejahatan sebagai gejala kemanusiaan (human phenomenon), yaitu kejahatan merupakan suatu manifestasi dari kepribadian pelaku. $^{43}$

Perlu kiranya dikemukakan, bahwa pendekatan humanistis yang bertolak dari konsepsi kejahatan sebagai "a personal disease" atau "a human or individually pathological phenomenon" harus pula diseimbangkan dengan pendekatan humanistis yang bertolak dari konsepsi kejahatan sebagai " $a$ socially disease" atau sebagai "a socially pathological phenomenon". ${ }^{44}$

\footnotetext{
${ }^{43}$ Stanley E.Grup, Op.Cit, hlm. 309 - 316.

${ }^{44}$ Ibid.
} 
Jika dikaitkan dengan ketentuan Perda Kota Bandar Lampung Nomor 8 Tahun 2000 sebagaimana telah dikemukakan di atas, maka penetapan pidana dalam ketentuan ini dapat dikatakan merupakan pendekatan yang paling efektif dari segi pendekatan kebijakan dan pendekatan nilai. Sebagai kebijakan, ketentuan pidana yang ada dalam Perda tersebut merupakan suatu usaha atau kegiatan untuk menyadarkan masyarakat mengenai tanggung jawabnya sebagai anggota masyarakat. Sebagai sebuah kebijakan, maka pendekatan pemberian pidana dalam Perda ini merupakan perjuangan penanaman kesadaran masyarakat yang terus menerus tak kenal henti.

Moeljatno mendefinisikan perbuatan pidana sebagai perbuatan yang dilarang oleh suatu aturan hukum, larangan mana disertai ancaman (sanksi) yang berupa pidana tertentu bagi barang siapa melanggar larangan tersebut . Larangan ditujukan kepada perbuatan (suatu keadaan atau kejadian yang ditimbulkan oleh kelakuan orang), sedangkan ancaman pidana ditujukan kepada orang yang menimbulkan kejadian itu. ${ }^{45}$

Di lain pihak, dilihat dari segi nilai, maka adanya ketentuan pidana di dalam perda tersebut menekankan pada perasaan kewajiban moral pada diri individu untuk bertanggung jawab dan oleh karena itu mencoba untuk merangsang ide tanggungn jawab/kewajiban sosial terhadap anggota masyarakat yang lain dan juga mendorongnya untuk menyadari moralitas sosial. Melalui pendekatan ini diharapkan, akan tercipta Kota Bandar Lampung yang tertib, rapi, dan indah sebagaimana yang dituju dalam pembentukan Perda Nomor 8 Tahun 2000.

\section{Penutup}

Berdasarkan pembahasan yang telah dilakukan, dapat diambil kesimpulan bahwa penggunaan sarana penal atau (hukum) pidana dalam suatu kebijakan merupakan cara untuk mengefektifkan pelaksanaan peraturan. Selain itu dapat disimpulkan bahwa adanya pidana dalam suatu peraturan hanya akan efektif apabila:

a. pidana itu sungguh-sungguh mencegah;

b. pidana itu tidak menyebabkan timbulnya keadaan yang lebih berbahaya atau merugikan daripada yang akan terjadi apabila pidana itu tidak dikenakan; dan

c. tidak ada pidana lain yang dapat mencegah secara efektif dengan bahaya atau kerugian yang lebih kecil.

Pemberian sanksi pidana dalam suatu peraturan, berfungsi mencegah terjadinya kejahatan, dan selain itu jika kejahatan telah terjadi, maka fungsi ketentuan pidana adalah untuk memberi efek jera bagi pelakunya.

\footnotetext{
${ }^{45}$ Moelyatno, Asas-asas Hukum Pidana, Rineka Cipta, Jakarta, 1993
} 
Dapat disimpulkan juga sebagaimana definisi tentang politik hukum pidana bahwa, politik hukum pidana mencakup tindakan memilih nilai-nilai dan menerapkan nilai-nilai tersebut di dalam kenyataan. Politik hukum pidana merupakan pemilihan terhadap nilai-nilai untuk mencegah terjadinya delikuensi dan kejahatan. Politik Hukum bertugas untuk meneliti perubahanperubahan mana yang perlu diadakan terhadap hukum yang ada agar memenuhi kebutuhan-kebutuhan baru di dalam kehidupan masyarakat.

Sebab itu disarankan agar peraturan lebih efektif keberlakuannya untuk memberikan ketentuan sanksi pidana bagi pihak yang melanggar ketentuan suatu peraturan perundang-undangan.

\section{Daftar Pustaka}

\section{A. Buku}

Alper, Benedict A., 1993. Changing Concept of Crime And Criminal Policy, UNAFEI No. 6/1993.

Andenaes, J., 1995. The General Part of the Criminal Law of Norway.

Arief, Barda Nawawi, 1992. Bunga Rampai Hukum Pidana, Bandung: lumni.

, 1980. Masalah Pemidanaan Sehubungan dengan Perkembangan Kriminalitas dan Perkembangan Delik-Delik Khusus dalam Masyarakat Modern, BPHN, Dep. Kehakiman.

Bassiouni, M. Cherif, 1998. Substantive Criminal Law.

Christiansen, Karl O., 1994. Some Consideration on the Possibility of a Rational Criminal Policy, Resource Material Series, No. 7, Tokyo: UNAFEI.

Hamdan, M., 1999. Politik Hukum Pidana. Jakarta: Penerbit PT Raja Grafindo Persada.

Hoderich, Ted, 1971. Punishment, London: Penguin Books.

Kassebaum, Gene, 1994. Delinquency and Social Policy.

Moelyatno, 1993. Asas-asas Hukum Pidana, Jakarta: Rineka Cipta.

Muladi, dan Barda Nawawi Arief, 1982. Pidana dan Pemidanaan.

Bandung: Alumni. , 2005. Teori-teori dan Kebijakan Pidana,

Packer, H.L., 1998. The Limits of Criminal Sanction.

Prasetya, Teguh, dan Abdul Halim barkatullah, 2005. Politik Hukum Pidana Kajian Kriminalisasi dan Dekriminalisasi, Yogyakarta: Pustaka Pelajar.

Ross, Alf, 1995. On Guilt Responsibility and Punishment.

Sadli, Saparinah, 1996. Persepsi Sosial Mengenai Perilaku Menyimpang

Smith, and Hogan, 1998. Criminal Law, 4th. ed. 
Grupp, Stanley E., 1991, Theories of Punishment.

Sudarto, 1997. Hukum dan HukumPidana, Bandung: Alumni.

, 1985. Hukum Pidana dan Perkembangan Masyarakat Kajian Pembaharuan Hukum Pidana, Bandung: Sinar Baru. 1982. Kapita Selekta Hukum Pidana. , 1996. Suatu Dilema dalam Pembaharuan Sistem Pidana Indonesia, cetakan ke-2.

\section{B. Lain-lain}

Clifford, W., Reform in Criminal Justice in Asia and the Far East, Resource Material Series No. 6, UNAFEI, 1993

Saleh, Roeslan, 1995, Mencari Azas-azas Umum yang Sesuai untuk Hukum Pidana Nasional, Kumpulan bahan upgrading hukum pidana. 